\title{
Protecting wild land from wind farms in a post-EU Scotland
}

\author{
Simon Marsden ${ }^{1}$
}

Accepted: 27 October 2017/Published online: 4 November 2017

(c) The Author(s) 2017. This article is an open access publication

\begin{abstract}
Scotland is one of the places in Europe to have experienced significant wind farm development over recent years. Concern about impacts on wild land has resulted in legal challenges based on European Union (EU) law. This article analyses whether wild land can be protected from wind farms and the differences that the United Kingdom departure from the EU will make. It considers the concept of 'wild land' compared with 'wilderness', analyses the legal basis (if any) for wild land protection and examines potential impacts from wind farms. It highlights the significance of EU environmental law, particularly nature conservation and environmental assessment law, and analyses recent Scottish jurisprudence that has applied this. The role of the European Commission and Court of Justice of the EU (CJEU) is emphasised as a key part of EU environmental law. The article asks whether relevant global and regional environmental agreements can effectively replace the content of the substantive law and context of the Commission and CJEU. Four environmental agreements and two related compliance procedures are briefly evaluated. The conclusion is that while EU law does not directly provide protection for wild land, it is considerably stronger than the international environmental agreements that may replace it.
\end{abstract}

Keywords Wild land $\cdot$ Scotland $\cdot$ Wind farms $\cdot$ EU law $\cdot$ Environmental agreements

\section{Introduction}

This article is a case study of the potentially impending regulatory and interpretative issues that may follow the UK decision to leave the EU. It analyses the implications of EU environmental law no longer binding the UK, particularly in relation to the protection of

Simon Marsden

simon.marsden@stir.ac.uk

1 Law School, University of Stirling, Stirling, Scotland FK9 4LA, UK 
wild land from wind farms in Scotland. Wild land is the closest type of terrain in the UK to retain qualities closest to those found in global wilderness. Recent extensive wind farm development or approvals may negatively impact upon offshore and onshore areas including this land, raising questions about the effectiveness of the law in providing protection (MacNab 2017; Author unknown 2016). Although there are no specific legal protections for wild land, EU nature conservation and environmental assessment law are relevant. Does this protect-or have potential to protect-wild land, or can it be reformed to do so? Furthermore, what alternatives exist in international law if the UK leaves the EU, and EU law no longer applies?

As a result of the 23 June 2016 UK-wide referendum on EU membership, a small majority of the British electorate decided to leave the EU, known as 'Brexit' (British exit). While not legally binding, nor approved by a majority of Scottish voters, the UK Government decided to implement the outcome. What difference will this make to the protection of wild land in Scotland? Will any international treaties be able to protect wild land? The real focus of the argument relates both to these questions, but must contend with the uncertainty about what Brexit means, and indeed, whether it will ever eventuate. The article therefore deals with a range of scenarios, from the withdrawal of all EU law to maintenance of the status quo. Since the referendum, it has become clear that there are many stakeholders, including constituent parts of the UK. This is particularly so of Scotland, because of the majority opposition to the vote (Carrell and Morris 2016). Baldock et al. comment (2016: 6):

The devolved administrations in Scotland, Wales and Northern Ireland would have an interest in many aspects of the new agreements to emerge and would have an important part in developing post-EU policies, which are therefore unlikely to be uniform within the UK.

The significant controversy about the decision and proposed executive-led approach has resulted in court cases in England (Sparrow 2016) and Northern Ireland (McDonald 2016) and led to daily political criticism across the UK and EU which is reported by the major newspapers. ${ }^{1}$ Ironically, the Court of Justice of the European Union (CJEU) may even be called upon to consider the legalities, especially in any transitional arrangements (Editorial 2017; Merrick 2016). Concerns have been raised about the consequences for environmental protection, the focus of this article (Reid 2016b, 2017; Scottish Government 2016a; Harvey 2016). If Brexit eventuates, EU environmental law will no longer be enforced by the EU in the UK, including Scotland, whether or not it continues to implement EU environmental law domestically through the previous transposition of directives (Ross et al. 2009). The reason is because the powers of the CJEU and the European Commission (EC) will come to an end, whatever transitional arrangements are put in place. These two institutions have provided the 'accountability for environmental standards' (Lee 2017), the 'big sticks of Commission-plus Court of Justice enforcement mechanisms and fines' (Lee 2017: 89), the context for law-making which has been as important as the content in the UK and Scotland. If these no longer exist, the creation of an independent body is recommended, to provide similar levels of scrutiny.

\footnotetext{
${ }^{1}$ Other than the specific references cited in the text, see, for example, the online accessible: The Guardian (https://www.theguardian.com/politics/eu-referendum) and The Independent (http://www.independent.co. $\mathrm{uk} /$ ) for ongoing coverage, and in relation to Scotland, The Scotsman (http://www.scotsman.com/news/ politics/eu-referendum). More detailed up-to-date scholarly commentary can also be located in The Conversation (https://theconversation.com/uk/eu-referendum-2016) and the Huffington Post (http://www. huffingtonpost.co.uk/news/article-50/).
} 
As to how EU law may be unwound, the position of the UK Government was indicated in a white paper in March 2017 (Department for Exiting the European Union 2017). If approved by Parliament, a 'Great Repeal Bill' will convert the 'acquis communautaire' (the body of European legislation) into domestic law at the same time as the repeal of the European Communities Act (under which the UK first joined the then EEC). This is currently passing through the Westminster Parliament (UK Parliament 2017) and is the subject of heavy criticism, in part because of the decision to limit Parliamentary scrutiny (Asthana 2017). While nothing was said in the white paper about the position of the CJEU (Watts 2017), ${ }^{2}$ any changes to the acquis will be decided by the Westminster or Holyrood (in the case of Scotland where it has devolved responsibility) Parliaments thereafter; the Scottish Government has, however, also criticised the UK Government for not respecting the current constitutional arrangements (Bews 2017). ${ }^{3}$ The transposition of directives into domestic environmental law means that domestic law in each jurisdiction will also need to be considered in considerable detail if it is also to be changed following Brexit (Reid 2016a: 409):

[T]here is no easy way of identifying and isolating the EU elements in the law applying within the UK. A simple measure saying that all EU laws no longer have legal force would not eliminate all of the EU legacy since measures wholly embedded in UK legislation would continue unaffected. It would also leave large chunks of UK law with major holes which would in effect prevent them from operating and open up a legal vacuum in areas where there would be no valid legal rules at all.

The article addresses the prospect of a 'post-EU Scotland' by considering both the potential loss of EU law and the alternatives to it. Domestic law is not the focus, but the potential of successor environmental agreements to protect wild land from wind farms in Scotland. These are either mixed agreements entered into by both the UK and EU, or have been entered into separately by the UK. If EU law no longer applies because domestic implementing law is unwound, international environmental agreements may have a very large gap to fill. This will extend beyond the content of the individual laws to the context in which they are implemented, enforced and complied with. Enforcement by the EC and judicial oversight provided by the CJEU are not likely to be replaceable by court procedures under international law (Jacobs 2006). These are considered weak in relation to enforcement and compliance and are in any event primarily concerned with transboundary disputes between states.

The article reviews the significance of two relevant agreements in particular: the Convention on the Conservation of European Wildlife and Natural Habitats (1979), the 'Bern Convention', and the Convention on Wetlands of International Importance, especially as Waterfowl Habitat (1971), the 'Ramsar Convention'. The Protocol on Strategic Environmental Assessment to the Convention on Environmental Impact Assessment in a Transboundary Context (2003), the 'Kiev Protocol', and the Aarhus Convention on Access to Information, Public Participation in Decision-Making and Access to Justice in Environmental Matters (1998), the 'Aarhus Convention', are also analysed for their impact upon domestic law. Each of these is to some degree reflected in EU law, but only the Bern Convention, Aarhus Convention and SEA Protocol have jurisprudential-like procedures

\footnotetext{
2 See Sections 4, 5 and 6, UK Parliament, European Union (Withdrawal) Bill 2017-2019 for more detail.

${ }^{3}$ See Sections. 10 and 11(1), UK Parliament, European Union (Withdrawal) Bill 2017-2019 for more detail.
} 
(Treves et al. 2009) accessible to the public which can potentially replace some of the context in which the EU directives operate. Reliance upon international courts to achieve the same as the CJEU is not likely to be as effective.

The analysis is directed towards three key research questions. First, does EU environmental law provide protection for wild land in Scotland, or if not, can it potentially be reformed to do so? This is relevant because of the uncertainties about Brexit noted above, the support from the Scottish Government for continued EU membership (Scottish Government 2016b) and Scotland's constitutional situation in relation to the rest of the UK (Peterkin 2017); EU protection for wild land is also relevant to other member states. Second, if for whatever reason EU environmental law is not able to provide this protection, can international environmental agreements replace EU environmental law in potentially protecting wild land in Scotland? Third, even if they have relevant content, are judicial or quasi-judicial procedures available and adequate to fill the contextual interpretation and enforcement gap currently provided by the EC and CJEU?

The research approach is an analysis of the content of the European and international legal instruments relating to wild land and wind farm development in Scotland in particular. Recent judicial reviews by Scottish courts of ministerial decision-making-and appeals to the UK Supreme Court-with reference to EU environmental law, and compliance procedures in international agreements, will be a focus. This will highlight that even if EU law is incorporated into domestic law, it will not benefit from future reform of EU law and policy; it will also emphasise the loss of the jurisprudential interpretation and enforcement powers of the CJEU and EC. Given the contentious constitutional nature and implications of Brexit for the EU, UK and Scotland, and the tensions between the economics and climate change benefits of wind farms versus wild land protection, the relationship between politics, law and economics is also highlighted, particularly in recent media commentary.

The structure is as follows. Section 2 considers the concept of 'wild land' and examines potential impacts from wind farms. Section 3 highlights the significance of EU environmental law, particularly in connection with potentially protecting wild land, and analyses recent Scottish jurisprudence that has applied EU law, which is important in potentially filling any hole left by the role of the CJEU. The role of the EU judicial branch and the EC in relation to substantive law is therefore analysed in providing the context of EU environmental law. Section 4 evaluates whether relevant global and regional environmental agreements can effectively replace EU environmental law, with further reference to Scottish case law and appeals to the UK Supreme Court. Both the substantive law and compliance controls of the relevant international environmental agreements are considered, given the added effect that the loss of the enforcement power of the EC and judicial powers of the CJEU will create to the effectiveness of the law. Section 5 draws conclusions in relation to the research questions.

\section{Wild land and its protection from wind farms}

Defining wild land is not a simple matter. It relates to wilderness, which has been defined further to three criteria or qualities: naturalness, undevelopedness and relative large size (Bastmeijer 2016a: 33). Wild land may, however, be better understood and accepted as a concept (McMorran et al. 2008). The EC (2013a, b) has distinguished between both wild land and wilderness based on levels and effect of human activity (Sect. 3 below); however, 
this does not necessarily affect the application of these criteria to wild land as well as wilderness, and this is the approach taken here. Wild land has just been more significantly adapted, but retains aspects of these criteria which can be mapped (Scottish Natural Heritage 2003), or scientifically modelled.

Carver (2016: 54) notes that '[s]ome of the most detailed modelling of wilderness quality to date has been carried out in Scotland for the two national parks: The Cairngorm National Park and the Loch Lomond and The Trossachs National Park'. He emphasises the impetus provided by both a European resolution and guidelines (below) to the measures introduced by the Scottish Government to 'forge ahead and produce two key outputs' (at 44). These were a consultancy review of wild land conservation in Europe (Fisher et al. 2010), and a detailed wildness map adapted from the work for the Scottish National Parks (Carver et al. 2012; Scottish Natural Heritage 2012a).

Protecting wild land is, however, not as straightforward as identifying it, as the discussion in relation to the designation of Natura 2000 sites and the legal protection under Article 6 of the Habitats Directive below highlights. This article addresses both the deficiencies of current EU legal protections and the inadequacies of the international treaties that will be focused upon if EU law ends. In relation to Brexit, if both EU and international law are ineffective, then domestic legal protection will be required. Part of the problem is that while aspects of biodiversity may be legally protected, landscape values are often not capable of effective protection (Fisher 2001). In the absence of protected area designation and enforcement therefore, maintaining the amenity values of wild land itself may be challenging. Although the European Landscape Convention (2000) provides some guidance, as with the other international agreements considered in Sect. 4, its objective is not specifically the protection of wild land. Article 1.a defines landscape as 'an area, as perceived by people, whose character is the result of the action and interaction of natural and/or human factors'. It was noted by Sarlöv-Herlin and Fairclough (2013: 2) that landscape assessments in the UK have:

...proved effective for helping to make planning decisions on, for example ...[how] wind farms ... should be fitted into the landscape... The method can also involve a systematic approach to assessing the sensitivity of different landscape areas to different types of change and new additions.

There have been significant declines in the area of the globe defined as wilderness (Watson et al. 2016), and wilderness mapping has highlighted the inadequacies of the extent of protected areas. It is because of these things that studies have reported on the state of the current law, and calls have been made for improved legislative protection for wilderness, wild areas (a term used by the EC) and wild land. Impacts from wind farms is a major issue in Scotland, exacerbated by support for them from the Scottish Government, which frequently permits them as a means of meeting climate change commitments (Scottish Government 2017; MacNab 2016b, 2017).

The potential impacts of wind energy upon nature and wildlife have been addressed at length in EU guidance (European Commission 2011a: 29-46), highlighting the challenge of balancing two environmental imperatives. The guidance emphasises that impacts are not always of a negative nature, particularly where wind farms are sited in areas of severely degraded land. It gives as an example Black Law wind farm in South Lanarkshire, previously used for opencast mining and not adequately remediated. It comments (at 30): 'ScottishPower devised and implemented a Habitat Management Plan for this brownfield site in consultation with Scottish Natural Heritage, RSPB Scotland, Lanarkshire Farmland and Wildlife Advisory Group and the University of Stirling'. 
Potential significant impact is therefore highly dependent upon location and affected species, with birds and bats especially vulnerable to terrestrial wild farms. A case by case approach is recommended to address likely major effects with reference to directives for strategic environmental assessment (SEA, Directive 2001/42/EC), environmental impact assessment (EIA, Directive 2014/52/EU) and Habitats (Directive 1992/43/EEC), the latter which are known as 'appropriate assessments'. These laws and the relationship between them is analysed in some detail in the next section, together with the significant role played by the CJEU and EC. Scottish courts have also considered the impact of wind farms upon protected areas, including wild land protection, which is also analysed.

\section{General effectiveness of EU law, lack of wild land protection and need for reform}

There is a voluminous literature on EU environmental law and its general effectiveness (e.g. Jans and Vedder 2012). The Natura 2000 Network comprises protected areas under the Habitats Directive (Special Areas of Conservation) and species protection under the Birds Directive (Special Protection Areas); these are collectively referred to as 'the cornerstones of the EU's biodiversity policy' (European Commission European Commission 2011a, b: 12; Directives 1992/43/EEC \& 2009/147/EC). Wild land is a very specific area, which is not directly protected. Given the different objectives of these directives, protection of wild land is largely dependent upon the interpretations of Natura 2000 (Bastmeijer 2016b). Article 6 of the Habitats Directive provides general procedural safeguards for protected areas from new developments, and this nature conservation law is the main means of protection. It responds to definitions of wilderness/wild land that emphasise biodiversity, or 'naturalness'. EU nature conservation law is also typically applied in conjunction with EU environmental assessment law, potentially providing additional protection.

The central aim of Natura 2000, as stated by Article 2(2) of the Habitats Directive, is to 'maintain or restore, at favourable conservation status, natural habitats and species of wild fauna and flora of Community interest'. Analysis of the relationship between wilderness and Natura 2000 designations has confirmed that 'almost all of the wildest places in the EU have a Natura 2000 status [although] only a small proportion ... has high wilderness qualities' (Bastmeijer 2016b: 189). Legal protection after designation depends on the application of conservation measures under Article 6(1)-(3), which Bastmeijer comments 'clearly limits the scope of legal protection of natural values' (190). 'Generally, one could state that the more wilderness-dependent habitats and species are, the stronger the "wilderness protection" (192). However, this does not mean that such protection is not without major limitations. Part of the problem is that certain species will not benefit, and those that do may not be protected in relation to all three qualities of naturalness, undevelopedness and relative large size. Bastmeijer gives as an example a wind turbines case, where Advocate General Mazak confirmed this, with various construction activities permitted. $^{4}$

Additional is the Article 6(4) derogation which allows plans or projects to go ahead where there are 'imperative reasons of overriding public interest' (notably social or economic). While there is clearly inadequate protection available for wild land under Article 6(1)-(3) in any event, Jackson, however, emphasises this is 'the sole legal means whereby

${ }^{4}$ Opinion AG Mazak, C-2/10, 14 April 2011, para 30. 
a Member State can allow a plan/project to proceed' (2014: 499). It is also used in the Scottish context when deciding whether wind farm development can proceed or not, with the public interest test applied in support of renewable energy development (Scottish Natural Heritage 2012b).

In 2009 the European Parliament passed a resolution on 'Wilderness in Europe' calling for Natura 2000 to: 'be strengthened further to become a coherent and functioning ecological network in which wilderness areas have a central place' (para 20). Guidelines distinguished between 'wilderness' and 'wild areas' based on degrees of human activity (European Commission 2013). Importantly, these identified the 'spatial link between wilderness and the Natura 2000 network' (European Commission 2013: 17), and in considering the EU Biodiversity Strategy in addition to the Natura directives, emphasised biodiversity (European Commission 2011b). Although these are important developments, unless and until they result in changes to the law-by either the introduction of a specific directive for example, or an interpretation by the CJEU-they do not strengthen the law as it stands. This highlights that while effective in many respects, where the protection of wild land in Scotland is concerned, EU environmental law has major limitations.

The conflict inherent in sustainable development, whereby clean energy is prioritised over wild land protection, explains this, and has been played out in the courts. In one case, the construction of 103 turbines by Viking Wind Farm across 80 square kilometres, which would disturb over 900,000 cubic metres of peatland, was successfully challenged in the Outer House of the Court of Session by the group 'Sustainable Shetland'. 5 Scottish Natural Heritage (SNH) also opposed the development because of its potential impacts upon a protected species as well as the landscape. Subsequently, in the Inner House, the Ministers' appeal was allowed. ${ }^{6}$ Boyle and Wheeler (2016: 527) emphasise that the outcome illustrates 'The tensions between national energy demands and landscape and wildlife protection'. Subsequent findings of the UK Supreme Court later confirmed that the discretion available to the Minister was sufficient to decide in favour of the developer. ${ }^{7}$

Woolley (2015) comments on the error of law argument whereby in the Outer House, Lady Clark advised that although her decision was based on a different ground, she would have accepted the petitioner's argument that the Ministers had not taken into account the Birds Directive, in particular the requirement of Article 4 that special conservation measures must consider the deteriorating condition of the affected species. The Inner House decided matters differently, with Lord Brodie arguing it was not necessary for the Ministers to identify and assess compliance with the Birds Directive once they had concluded there would be no significant impact. The UK Supreme Court position was that the Birds Directive was relevant. However, Lord Carnwath emphasised that representations were not made to the Scottish Ministers about the matters in dispute, and therefore the authorisation decision was valid. In considering whether the decision would have been different if these representations had been made, Woolley views this unlikely, given 'the finding of fact that the wind farm did not pose a significant threat'. (Woolley 2015: 428).

The RSPB case ('RSPB') concerned both the Birds and Habitats Directives, and particularly the relationship between the appropriate assessment process under the latter and the environmental assessment process under the EIA Directive (Directive 2014/52/EU). ${ }^{8}$

\footnotetext{
5 Sustainable Shetland v Scottish Ministers [2013] CSOH 158.

6 Sustainable Shetland v Scottish Ministers [2014] CSIH 60.

7 Sustainable Shetland v Scottish Ministers [2015] UK SC 4.

${ }^{8}$ Royal Society for the Protection of Birds v Scottish Ministers [2016] CSOH 103.
} 
The applicants sought review of the Scottish ministers' decisions to grant permission to the developer Inch Cape Offshore Wind Farm for four major projects in the Firth of Forth and Firth of Tay (RSPB undated). The Outer House of the Court of Session initially quashed all of the authorisations due to breaches of EU environmental law, finding that there would be negative effects upon the Forth Islands and Fowlsheugh SPAs. The concerns of the petitioner NGO (RSPB) were shared by the statutory nature conservation bodies, SNH and the Joint Nature Conservation Committee (representing the UK).

Lord Stewart's opinion in the Outer House was that the RSPB had been denied the opportunity to participate despite having a valuable contribution to make. He states (at para 238): 'I accept the evidence presented by the RSPB that the "appropriate assessment's" application of extended Band model option 3 is methodologically flawed;' and (at 243), "The "appropriate assessment" is flawed as a basis for considering the development authorisations'. McKie (2016: 2) highlights the importance of the case as a judicial review by another concerned group, although concedes that 'The ultimate outcome may be impacted by Brexit, as the basis of the success thus far in judicial review terms depends on breaches of EU Law'.

The effect of both Sustainable Shetland and RSPB for wild land protection is very limited. The first case was concerned only with the Birds Directive, the second did not concern terrestrial issues and the Inner House of the Court of Session in 2017 subsequently overturned the previous ruling. ${ }^{9}$ The mixed, limited support to EU environmental law hence emphasises the difficulties of using it to protect wild land, as well as for species of high value (McKenna 2017). The underlying tension between the high level of environmental protection and the challenge of addressing climate change remains in the discretion and derogations available. Analysing jurisprudence of wind farm development in connection with EU law, Boyle and Wheeler (2016: 531) conclude: 'This means that wildlife legislation is going to do very little, if anything, to prevent the loss of wild land in the UK and so increases the urgency for the need for the statutory protection of wild land in its own right'. Given the practice of Scottish Ministers in overturning local decisions in relation to wind farm development, this is significant recognition of the need for domestic legal protection.

Implementation of the Renewables Directive (2009a, b/28/EC) is another example of EU environmental law not providing protection from wind farms. After recitals running to 97 paragraphs emphasising the importance of renewable energy, among other obligations the Directive lays down mandatory national targets in Article 3 and requires national renewable energy action plans in Article 4. As to how it is perceived, Eriksen (2014: 276) comments: 'the European Commission has adopted a particular interpretation of the Renewables Directive, which limits the possibility for national authorities to use discretion in the process of authorising wind farms'. Despite this, it is notable that the CJEU has interpreted the directive as allowing legislation prohibiting wind turbines for commercial energy production on Natura 2000 sites, with no need for prior EIA provided the principles of non-discrimination and proportionality are respected. ${ }^{10}$ This at least is strong support for

\footnotetext{
${ }^{9}$ Opinion of the Court (Lord Carloway), Royal Society for the Protection of Birds $v$ Scottish Ministers [2017] CSIH 31. The RSPB has now appealed directly to the Supreme Court to overturn this after a request for leave to appeal from the Court of Session was refused, see: http://www.scottishlegal.com/2017/ 08/16/rspb-seeks-permission-from-supreme-court-to-appeal/\#.

${ }^{10}$ Case C-2/10, Azienda Agro-Zootecnica Franchini sarl and Eolica di Altamura Srl v Regione Puglia [2011] ECR 6561.
} 
EU law in protecting nature and is indicative of the role of the CJEU that would be lost following a departure from the EU.

EU environmental law therefore remains a potentially powerful means of providing protection for habitats, despite its limitations regarding the protection of wild land specifically. This is particularly so because of the significant role of the CJEU and generally - if not in the case of the Renewables Directive - the role of the EC (Scotford and Bowman 2017: 417). In relation to interpretation and application, rulings mainly come from actions for failure to fulfil obligations or from references for preliminary rulings. Jurisprudence has also confirmed fundamental principles, including the primacy of EU law over national law or liability of Member States for breaches of EU law; these will come to an end if the UK leaves the EU. ${ }^{11}$ Nature conservation cases have also contributed to clarifying obligations under the Birds and Habitats Directives and have strengthening the rights of the EU citizens (Sundseth and Roth 2014).

Given Boyle and Wheeler's (2016) emphasis above upon the importance of specific legislative protection for wild land, Bastmeijer (2016b) considers more detailed options available to the EU, which if in force after Brexit would, if not benefitting wild land protection in Scotland, would, however, benefit protection in other member states. Making wilderness/wild land protection an explicit policy aim to be established via Natura 2000 is suggested as an appropriate approach, following the Guidelines on Wilderness in Natura 2000 (European Commission 2013), which he comments 'adopt a cautiously optimistic tone' (194). Yet while they highlight the important role of the EC in their drafting, he acknowledges that 'Notwithstanding its wider significance, however, legal aspects receive little attention in the Guidelines' (194).

The reform suggestions made by Bastmeijer (2016b: 193-197) are limited by ecological change and the relationship with the conservation objectives which guide the legislative scheme of Natura 2000, and also preventing the extinction of habitats and species. Introducing wilderness zones and adopting stricter domestic standards - and preferably law for these-are, however, considered of benefit in enhancing current EU measures for other member states, whether or not Scotland would benefit from them. However, it is important to emphasise that while Article 6(3) of the Habitats Directive does not prevent absolute prohibitions on wind farms, proportionality and non-discrimination would need to be respected. A post-EU Scottish Government would potentially be unimpeded in taking such decisions, if a different course were taken with respect to wind farms and wild land protection.

Whether or not EU law is reformed to include specific protection for wilderness, the extent of the potential general loss of EU environmental law following Brexit will be considerable. Reid (2016a: 409-410) includes the highly significant role of the CJEU (at 413) and emphasises the stability of EU laws, which are 'well suited to tackling major environmental problems' (412), and which 'once made they stick around' (also at 412). He also lauds the EU preference for strict standards and targets, and highlights concerns for nature conservation law in particular (413):

Thus in an area such as nature conservation, there may not be a wholesale dismantling of the EU laws which give protection to designated species and habitats, but there might be a desire to relax the near absolute nature of the obligations set, so that conservation arguments can be overridden and development which has an adverse

11 See Schedule 1, Sections 4 and 5, UK Parliament, European Union (Withdrawal) Bill 2017-2019 for more detail. 
effect on a Special Area of Conservation or on a protected species can be permitted in circumstances well beyond the tightly confined derogations built into the EU laws.

\section{The questionable effectiveness of successor environmental agreements}

A growing number of studies have highlighted the implications of a UK departure from the EU, with one consequence the enhanced significance of international environmental agreements. The absence of comparable judicial interpretation and enforcement arrangements for these agreements (Stephens 2009), however, means they have neither the competence nor resources to match the CJEU, nor is there a body like the EC to ensure compliance. While international compliance procedures already operate in the UK/Scotland because agreements are in force, it is undeniable that these will not provide the same level of protection as EU law (Reid 2016a: 411):

The big difference, of course, is that whereas EU law is very detailed, the EU structures provide strong (if slow) measures to enforce compliance by states, and domestic courts ensure that individuals can enjoy the rights conferred by EU law, the same does not apply for international law.

There are numerous international environmental agreements in force potentially relevant to protect wild land from wind farms, for example the European Landscape Convention (2000) considered above. The European Commission outlined many of these in its wind energy/Natura 2000 guidance (European Commission 2011a, b: 26-28). This section emphasises the global Ramsar Convention, the regional Bern Convention and two UNECE regional agreements, the Kiev SEA Protocol and related Aarhus Convention. The first two are part of a cluster of biodiversity conventions (Velázquez Gomar 2016; Caddell 2011) and have a relevant substantive focus. The latter two are primarily procedural agreements, with the Aarhus Convention notable for its compliance procedure. The purpose of this section is not to analyse the requirements of these agreements in any detail-which is beyond the scope of this article-but to make simple comparisons in content and context with the EU law.

\subsection{The Bern conservation convention}

The Bern Convention is considered first because of its influential role in relation to Natura 2000. Although the EU is not a member, it was ratified by the UK on 28 May 1982 and entered into force on 1 September 1982. ${ }^{12}$ Like the Landscape Convention (above), it operates under the auspices of the Council of Europe. Trouwborst (2016: 162) believes it has strengthened European biodiversity conservation efforts and potentially provides protection for wilderness (and wild land) from wind farms:

...the protection requirements under the Convention regarding species and their habitats ...can have the effect of impeding the construction of human infrastructure (e.g., roads, wind turbines or cables) in areas with wilderness qualities.

Although the Convention contains strongly worded provisions for protection of habitats (Article 4) and species (Articles 5 and 6), Article 9(1) provides exemptions where, like the Habitats Directive, there are overriding public interests. Yet where these are not claimed,

12 See the Nature Conservation (Scotland) Act 2004 (as amended). 
obligations can be enforced via the case file approach of the Standing Committee, which has broad powers to deal with compliance (Article 9(2)), and matters can be submitted by NGOs and private citizens. The Standing Committee is the governing body of the Convention and includes all Contracting Parties as well as observer states and organisations. It meets annually to adopt recommendations to achieve the Convention's objectives and improve its effectiveness. It also monitors implementation and provides guidance. As with the Aarhus Convention and its Compliance Committee (below), it is very important as a potential replacement for the loss of the EU context that would follow Brexit.

An important objective is the creation of the Emerald Network of Areas of Special Conservation Interest, which operates alongside the Natura 2000 Network for EU member states. The UK has not proposed any sites for inclusion on this list, which hinders its operation. A Group of Experts on Protected Areas and Ecological Networks supports and monitors the implementation of recommendations. These include Recommendation 16 (1989) on Areas of Special Conservation Interest and Recommendation 25 (1991) on the conservation of natural areas outside protected areas. Recommendation 109 (2004) on the effects of wind turbines on migratory species of mammals and birds is particularly relevant, and in support of this, the NGO BirdLife International analysed environmental assessment criteria and site selection issues (Langston and Pullan 2003). Recommendation 109 states that the Contracting Parties are 'to take appropriate measures to minimise the potential adverse effects of wind turbines on wildlife, to involve the industry sector and to ensure adequate monitoring and surveillance to improve the understanding of the impact of wind farms'. ${ }^{13}$

\subsection{The Ramsar wetlands convention}

The Ramsar Convention applies to a specific type of area and is potentially significant for protecting wild land in Scotland because of the large number of sites inscribed (51) - in total about 313,000 hectares. ${ }^{14}$ Guidance also addresses the implications for wetlands of policies, plans and activities in the energy sector (Ramsar Convention 2012). The Convention was ratified by the UK on 1 May 1976 and came into force on 5 May 1976; like the Bern Convention, the EU is also not a member. The main obligations are to promote the conservation and wise use of wetlands (Article 3(1)) and inform other Parties of any changes in ecological character as a result of human interference [Article 3(2)]. It is deficient in key areas, however, partly because it 'lacks a provision that would oblige its signatories to establish an adequate legal mechanism with the purpose to ensure its efficient implementation and provide appropriate sanctions for its breach'. (Batanjski et al. 2016: 843).

However, the treaty has potential to provide international protection for wild land (and associated coastal and marine areas) from wind farms, if the UK or Scottish Governments

\footnotetext{
${ }^{13}$ Note also that the Conference of the Parties of the Bonn Convention on the Conservation of Migratory Species of Wild Animals also adopted a resolution on wind turbines and migratory species in 2002. This calls upon the Parties, inter alia to identify areas where migratory species are vulnerable to wind turbines and where wind turbines should be evaluated to protect migratory species. They should also apply and strengthen comprehensive strategic environmental impact assessments where major developments of wind turbines are planned, and take full account of the precautionary principle. See European Commission (2011a: 27).

14 Scottish National Heritage: http://www.snh.gov.uk/protecting-scotlands-nature/protected-areas/ international-designations/ramsar-sites/ As with the Bern Convention, the Ramsar Convention is also recognised by the Nature Conservation (Scotland) Act 2004 (as amended).
} 
decided to establish a legal mechanism preventing development on or close to such sites. Ramsar sites in Scotland are also Natura 2000 sites, and two are particularly notable: the Firth of Forth, and Caithness and Sutherland Peatlands. The Firth of Forth is partly coinscribed as both a Ramsar and Natura 2000 site and remains threatened as a result of the major offshore wind farms examined in the RSPB cases above. In relation to the Peatlands, this is also co-designated and-although beyond the scope of this article-national designations also apply which provide varying, limited protections which would need to be considered if these were the only means of protecting wild land after Brexit. ${ }^{15}$ Although Sutherland Peatlands clearly meets two of the wilderness criteria (scale and lack of disturbance), the third (lack of development) may shortly be compromised given the proximity of the approved development. The national description (Joint Nature Conservation Committee 2005) states:

The scale and diversity of the Caithness and Sutherland peatlands in northern Scotland make them unique in Europe. They form the largest peat mass in the UK and are three times larger than any other peatland area in either Britain or Ireland... a very high proportion of this ground remains undisturbed.

The site is therefore threatened after a decision to permit a major wind farm of 22 turbines (Highland Council 2015), despite being partly within a wild land area specifically designed to avoid this. Peatlands are easily disturbed, and their importance for biodiversity conservation is recognised (Joosten 2015). MacNab (2016a) comments on the permitting decision: 'The Creag Riabhach scheme in Altnaharra lies within the Wild Land Areas map which was unveiled by ministers 2 years ago to protect the natural heritage of Scotland. It came amid growing public concerns about the spread of windfarms onto untouched landscapes'. However, since inclusion on the map, the project has been supported by the Scottish Government (2016c) as a general component of its climate change strategy, by local communities keen to economically benefit, and by general supporters of wind power. Given competing interests, without legal protection wild land will continue to be lost, and 'Creag Riabhach could become the Trojan Horse for further industrialisation of Wild Land Areas' (John Muir Trust 2016).

The 2015 approval decision was recently challenged in a judicial review (Author unknown 2017), ${ }^{16}$ based in part upon the Scottish Planning Policy 2014 ('SPP 2014', Scottish Government 2014: para 200). This was not successful, with Lord Boyd commenting: 'the policy contained in SPP 2014 is more rigorous in the protection of wild land than previous policy. It is not, however an absolute prohibition against any development'. ${ }^{17}$ He concludes 'In short the petitioners' position appears to be that no windfarm development whatsoever should be allowed on designated wild land areas. That may be, but it is a political decision and not one for the courts'. ${ }^{18}$ The Wild Land Areas map (and/or Directive) therefore does not legally prevent development, only that adverse impacts should be minimised where possible (Highland Council 2015: para 8.38). Additionally, although to the west and south of the site, the Caithness and Sutherland Peatlands Ramsar

\footnotetext{
15 These include National Nature Reserves, Sites of Special Scientific Interest, National Parks and National Scenic Areas. See Scottish National Heritage: http://www.snh.gov.uk/protecting-scotlands-nature/protectedareas/national-designations/.

16 Opinion of the Court (Lord Boyd of Duncansby), Wildland Ltd and the Welbeck Estates v Scottish Ministers [2017] CSOH 113.

17 Ibid, para 40.

18 Ibid, para 45.
} 
site is in close proximity (Highland Council 2015: para 2.3), this imposes no restrictions on the development. Indeed, even if the development were proposed for the Ramsar site, this would not prevent it proceeding if the Government took the view that significant environmental effects were not likely, which is the standard consideration for decisionmakers with respect to EIA, whether domestic or international. ${ }^{19}$

\subsection{The Kiev Protocol on strategic environmental assessment}

The Kiev or 'SEA' Protocol was adopted by the UK on 21 May 2003 but unlike the EU (which did so on 12 November 2008), the UK has not ratified it. Its obligations are therefore not binding without it being an EU member state. Because EIA is important for reviewing wind farm developments but has limitations as a process for evaluating projects on a site by site basis, SEA is particularly important. It can also be used to evaluate a broader plan or program for wind farm development; Article 4(2) requires an SEA of plans and programmes prepared for the energy sector, and Annex II(15) makes reference to wind farms in this respect. SEA is therefore a key tool for protecting the environment, and EU law recognises this in relation to wind farm development alongside EIA (European Commission 2011a, b, 23; Lee et al. 2013, 46-48). ${ }^{20}$ In Scotland, this is also the case (Highland Council 2016 \& 2012).

While the SEA Protocol is similar to the EU SEA Directive (Jones and Scotford 2017) — which has, like other EU directives, been transposed into domestic law-there are a few notable differences. It does not contain a specific provision for assessing cumulative effects, does not have a clear link with nature conservation law and operates independently without a comparable relationship with domestic EIA (Marsden 2008: 280-281). Significantly the parent treaty, the Convention on Environmental Impact Assessment in a Transboundary Context (1991, see Marsden 2011) does not apply domestically. This means that an end to EU membership may-if the domestic implementation of the EIA and SEA Directives were also unwound-have greater implications for EIA than SEA. The SEA Directive can be replaced in part by the SEA Protocol; the EIA Directive cannot be replaced by the Espoo Convention because it does not operate domestically.

The SEA Protocol has been examined regarding renewable energy planning (UNECE 2016). In relation to context, in the same way that the Council of Europe and its institutions such as the Bern Convention Standing Committee may become more important for the UK and Scotland if EU membership ends, this is even more so in relation to the UN Economic Commission for Europe (UNECE). The reason is that the role of the UNECE in environmental policy making is considerable, and it is the only one of the five UN regional commissions to have produced any environmental treaties. These are effectively clustered (Marsden and Brandon 2015; Schrage et al. 2009) like the biodiversity conventions, and compliance bodies also collaborate with one another (UNECE 2015). In relation to the Aarhus Convention (below), Lee et al. (2013: 47) comment 'The SEA Directive is the primary mechanism by which the EU implements the 'plans and programmes' requirements in Article 7 of the influential Aarhus Convention'.

If the SEA Directive were unwound from domestic legislation, the SEA Protocol could-if ratified-replace it. Given the similarities in the provisions of each, and general

\footnotetext{
19 See Certain Activities Carried out by Nicaragua in the Border Area (Costa Rica v. Nicaragua), Judgment, 16 December 2015, ICJ Reports 2015 ('Costa Rica v. Nicaragua/Nicaragua v. Costa Rica'), para 109.

${ }^{20}$ In Walton v Scottish Ministers [2012] UKSC 44, para 14 Lord Reid referred to the complementary relationship between the SEA and EIA Directives..
} 
acceptance of the obligations-particularly by the Scottish Government which has gone further than the other UK jurisdictions in this respect (Jackson and Illsley 2006), ${ }^{21}$ this is highly unlikely, however. What is more important is whether the SEA procedures in place will be used to avoid the cumulative impacts from large wind farms. Given the concerns expressed about the 'further industrialisation of Wild Land Areas' by the John Muir Trust (2016), the potential for impact upon these areas-even where farms are located outside but in close proximity to them-will grow as their numbers increase. Proactively applying SEA to avoid such effects will be needed.

\subsection{The Aarhus Convention on public participation}

The Aarhus Convention was ratified by the UK on 23 February 2005 (the EU on 17 February 2005), and it came into force afterwards. It has been a significant contribution to enhancing and enforcing procedural aspects underlying environmental law, including EU nature conservation law. ${ }^{22}$ Its obligations have been implemented across the state Parties, including the EU which is also bound (Pallemaerts 2011; Marsden 2012). In the UK in general, it has been influential across all three pillars (Banner 2015), has been heavily applied in relation to the energy context (Lee et al. 2013), and it is very relevant in Scotland (McCartney 2011).

The role of the Aarhus Convention Compliance Committee (ACCC) is particularly significant because of the opportunities available for the public to access the procedure. As an example, the Renewables Directive was found to have breached EU law (above), and the EU was found non-compliant with Article 7 in relation to national renewable energy action plans and required to 'adopt a proper legislative framework for implementing article 7' (ACCC 2010; Lee et al. 2013: 52). The ACCC can readily be approached by those who have exhausted domestic avenues of redress to challenge procedural failings related to wind farm development, whichever of the three pillars has been potentially breached.

Drummond (2015) reviews the implementation of the Aarhus Convention in relation to EU law and the development of case law and legislation in Scotland. Of particular relevance is the case concerning Argyll Wind Farm (ACCC 2014), whereby 'The Committee concludes that because the United Kingdom's [National Renewable Energy Action Plan] NREAP was not subjected to public participation, the Party concerned (United Kingdom) failed to comply with article 7 of the Convention, in this regard'. (at 16). (Metcalfe 2012; Pagano 2013). Despite the gains achieved by those who have taken cases to the ACCC, however, it cannot be compared with the role of the CJEU, as despite continuing deficiencies given access, time and cost, still has the advantages of enforceability and relative accessibility (Marsden 2012). Reid (2016b: 414) comments:

[I]ts decisions lack the full force of law enjoyed by decisions of the Court of Justice so that even if an authority's actions were held to have breached the Convention, that does not mean that it was acting unlawfully as a matter of domestic law. There are also fewer opportunities for individuals and groups to take the initiative in the international sphere, as opposed to the potential for complaints to the Commission or litigation where EU law confers rights.

21 See http://www.gov.scot/Topics/Environment/environmental-assessment/sea.

22 See Case C-240/09, Lesoochranárske zoskupenie VLK v Ministerstvo žvotného prostedia Slovenskej republiky [2011] 2 CMLR 43, which concerned the Habitats Directive and the effect of Article 9(3) of the Aarhus Convention. 


\section{Conclusions}

The first research question asked whether EU environmental law provides protection for wild land in Scotland, or if not, can it potentially be reformed. The answer to the first part is no, because there are no specific laws to protect these areas. While EU directives review potentially impacting wind farm development, there are no absolute prohibitions. Yet if EU nature conservation law is removed from the statute books, this will still be a major setback. While it may not directly protect wild land, it does protect the biodiversity essential for the 'naturalness' criterion to be met. In addition, the application of EU environmental assessment law makes analysis of significant effects a central part of the process to meet the 'undevelopedness' criterion. The third, the criterion of scale, is supported by both nature conservation and environmental assessment law, to ensure effective functioning of ecological processes. As to the second part of the first research question, the resolution of the European Parliament and EC guidelines began the reform discourse, indicating clear potential for this in conjunction with Natura 2000. Yet clear legal provisions that can be transposed into domestic law are essential.

The second research question asked whether, if EU environmental law is not able to provide protection, can international environmental agreements do so. The answer is perhaps, but, like the current EU directives, the level of protection would also be limited, and in fact more so. The Ramsar Convention contains inadequate or no provisions in relation to protection, and in 2015 the International Court of Justice emphasised the weakness of these provisions. ${ }^{23}$ Unless this first generation treaty is considerably updated, it will not replace Natura 2000 if EU law is unwound from domestic law. The Bern Convention holds more promise, and as a European based agreement with close links with Natura 2000, it is far more likely to provide comparable protections.

As to the SEA Protocol, while the similarities with SEA Directive are an advantage in examining whether it can replace the EU law, it must be ratified first and EIA would also need to remain on the statute books for the link between SEA and EIA to be maintained. If there is no EIA, there is less need for SEA, as the relationship between the plans and programmes which set the framework for individual development projects will end. However, perhaps partly because the EIA and SEA Directives do not prevent development per se, they are unlikely to be unwound from Scottish law and will remain a valuable tool to mitigate the worst negative effects of development. Finally, the obligations of the Aarhus Convention have mostly been transposed by the relevant directives, and subsequently into domestic law, so this law is likely to continue unless the UK decides to withdraw from the treaty.

The third research question asked whether, even if the international environmental agreements have relevant content, procedures are available and adequate to fill the contextual interpretation and enforcement gap currently provided by the EC and CJEU. The answer to this is no, neither of the agreements is informed by detailed jurisprudence comparable with that of the Habitats and Birds Directives generated by the CJEU, or as applied in the domestic courts. The structure and accessibility of the international judicial system largely denies rights to individuals and NGOs, meaning that opportunities to challenge compliance failings by the state are either impossible or very limited.

The continuance of the Aarhus Convention will, however, likely ensure that the modest protections it provides will, however, remain, in particular the ACCC procedure. However,

${ }^{23}$ Note 19 above. 
as with other arrangements, such as the Bern Convention Standing Committee case file procedure, there are significant limitations compared with the role of the CJEU, in particular when it comes to enforcement. Protecting wild land from wind farms is therefore likely to be even more difficult in a post-EU Scotland. The UK and devolved administrations will be able to decide on the content of the domestic law. They will also be able to steer discretionary decision-making, which will be subject only to non-enforceable declarations of non-compliance, whatever the potential for 'naming and shaming'.

Overall, because of the weakness of the obligations contained within the international agreements, and lack of an effective means of ensuring compliance, it can be said that none of them imposes any real restraint on Scotland supporting wind farm development via domestic law. While EU law is currently no panacea for avoiding or mitigating potentially significant environmental effects from wind farms upon wild land, the content of this law has made - and continues to make-a difference in a number of important ways. EU nature conservation law has introduced a detailed regulatory scheme for protecting places and species via Natura 2000, and environmental assessment law evaluates potentially significant negative effects from wind farms. The CJEU and EC have demonstrated a willingness to enforce this law because of the powers available to them. Even if the successor environmental agreements can be argued to have comparable obligations-which they do not-their enforcement context will be considerably weaker. Unless domestic law therefore introduces protective provisions for wild land, the prospects in a post-EU Scotland are hence poor.

\section{Compliance with ethical standards}

Conflict of interest The author declares that he has no conflict of interest.

Open Access This article is distributed under the terms of the Creative Commons Attribution 4.0 International License (http://creativecommons.org/licenses/by/4.0/), which permits unrestricted use, distribution, and reproduction in any medium, provided you give appropriate credit to the original author(s) and the source, provide a link to the Creative Commons license, and indicate if changes were made.

\section{References}

ACCC. (2010). ECE Meeting of the Parties to the [Aarhus] Convention, Compliance Committee Thirtyninth meeting Geneva, 11-14 December 2012, Findings and recommendations with regard to communication ACCC/C/2010/54 concerning compliance by the European Union. Adopted on June 29, 2012. ECE/MP.PP/C.1/2012/12.

ACCC. (2014). ECE Meeting of the Parties to the [Aarhus] Convention, Compliance Committee Fortyfourth meeting Geneva, 25-28 March 2014, Findings and recommendations with regard to communication ACCC/C/2012/68 concerning compliance by the European Union and the United Kingdom of Great Britain and Northern Ireland. Adopted September 24, 2013. ECE/MP.PP/C.1/2014/5, 13 January 2014.

Asthana, A. (2017). Brexit bill: Senior Conservatives warn May after vote for second reading. London: The Guardian.

Author unknown. (2017). Billionaire challenges Scottish ministers' turbines decision. London: BBC News. http://www.bbc.co.uk/news/uk-scotland-highlands-islands-40192565.

Author unknown. (2016). Danish landowner's fury over wild land wind farm. Golspie: The Northern Times. http://www.northern-times.co.uk/News/Danish-landowners-fury-over-wild-land-wind-farm-23122016. htm.

Baldock, D., Farmer, A., \& Nesbit, M. (2016). Brexit-The implications for UK environmental policy and regulation: A special independent report commissioned by the all-party parliamentary environment group (pp. 1-24). London: Institute for European Environmental Policy.

Banner, C. (Ed.). (2015). The Aarhus Convention-A guide for UK lawyers. Oxford: Hart Publishing. 
Bastmeijer, K. (2016a). Introduction. In K. Bastmeijer (Ed.), Wilderness protection in Europe-The role of international, European and national law (pp. 3-37). Cambridge: Cambridge University Press.

Bastmeijer, K. (2016b). Natura 2000 and the protection of wilderness in Europe. In K. Bastmeijer (Ed.), Wilderness protection in Europe-The role of international, European and national law (pp. 177-198). Cambridge: Cambridge University Press.

Batanjski, V., Batrićević, A., Purger, D., Alegro, A., Jovanović, S., \& Joldžić, V. (2016). Critical legal and environmental view on the Ramsar Convention in protection from invasive plant species: An example of the Southern Pannonia region. International Environmental Agreements, 16, 833-848.

Bews, L. (2017). Brexit: Westminster acting as if devolution 'never happened'. Edinburgh: The Scotsman.

Boyle, S., \& Wheeler, N. (2016). Wilderness protection in the United Kingdom. In K. Bastmeijer (Ed.), Wilderness protection in Europe-The role of international, European and national law (pp. 507-535). Cambridge: Cambridge University Press.

Caddell, R. (2011). The integration of multilateral environmental agreements: Lessons from the biodiversity-related conventions. Yearbook of International Environmental Law, 22(1), 37-75.

Carrell, S., \& Morris, S. (2016). Court allows Scotland and Wales to intervene in article 50 case. London: The Guardian.

Carver, S. (2016). Mapping wilderness in Europe. In K. Bastmeijer (Ed.), Wilderness protection in EuropeThe role of international, European and national law (pp. 38-66). Cambridge: Cambridge University Press.

Carver, S. J., Comber, A., McMorran, R., \& Nutter, S. (2012). A GIS model for mapping spatial patterns and distribution of wild land in Scotland. Landscape and Urban Planning, 104, 3-4.

Convention on Access to Information, Public Participation in Decision-Making and Access to Justice in Environmental Matters. (1998). In UN Treaty Series 2161, UN Economic Commission for Europe, Aarhus, Denmark.

Convention on Environmental Impact Assessment in a Transboundary Context. (1991). In International Legal Materials, 30, UN Economic Commission for Europe, Espoo, Finland.

Convention on the Conservation of European Wildlife and Natural Habitats. (1979). In European Treaty Series No 104, Council of Europe, Bern, Switzerland.

Convention on Wetlands of International Importance especially as Waterfowl Habitat. (1971). In UN Treaty Series No 14583. As Amended by the Paris Protocol, 3 Dec 1982, \& Regina Amendments, 28 May 1987, Ramsar, Iran.

Department for Exiting the European Union. (2017). Legislating for the United Kingdom's withdrawal from the European Union. Cm 9446.

Directive 1992/43/EEC on the conservation of natural habitats and of wild fauna and flora. In Official Journal of the European Union L206/7.

Directive 2001/42/EC on the assessment of the effects of certain plans and programmes on the environment. In Official Journal of the European Union L197/30.

Directive 2009/147/EC on the conservation of wild birds. In Official Journal of the European Union L 20/7.

Directive 2009/28/EC on the promotion of the use of energy from renewable sources and amending and subsequently repealing Directives 2001/77/EC and 2003/30/EC. In Official Journal of the European Union L 140/16.

Directive 2014/52/EU amending Directive 2011/92/EU on the assessment of the effects of certain public and private projects on the environment. In Official Journal of the European Union L 124/1.

Drummond, L. (2015). The Aarhus Convention in Scotland. In C. Banner (Ed.), The Aarhus Convention-A Guide for UK Lawyers (pp. 41-72). Oxford: Hart Publishing.

Editorial. (2017). The Government's position on British law after Brexit is worryingly vague. London: The Independent. http://www.independent.co.uk/voices/editorials/ecj-brexit-law-making-british-judiciaryeurope-repeal-billa7882826.html.

Eriksen, C. C. (2014). Constraining administrative discretion to facilitate renewable energy: Wind farms as a challenge for EU law and the European Commission. Journal of Energy \& Natural Resources Law, 32(3), 273-295.

European Commission. (2011a). Wind energy developments and Natura 2000, guidance document. Luxembourg City: Publications Office of the European Union.

European Commission. (2011b). Our life insurance, our natural capital: an EU biodiversity strategy to 2020. In: Communication from the Commission to the European Parliament, the Council, the Economic and Social Committee and the Committee of the Regions (COM(2011) 244 final, 2011).

European Commission. (2013a). The EU Biodiversity Strategy to 2020. City of Brussels: European Union.

European Commission. (2013b). Guidelines on wilderness in Natura 2000-Management of terrestrial wilderness and wild areas within the Natura 2000 network. City of Brussels: European Union. 
European Landscape Convention. (2000). In European Treaty Series 176. Florence, Italy: Council of Europe.

European Parliament. (2009). Resolution of 3 February on wilderness in Europe (2008/2210(INI)). OJ C $67 E, 18.3 .2010$, p. 1-4.

Fisher, D. E. (2001). Can the law protect landscape values? New Zealand Journal of Environmental Law, 9 , $1-49$.

Fisher, M., Carver, S., Kun, Z., McMorran, R., Arrell, K., \& Mitchell, G. (2010). Review of status and conservation of wild land in Europe., Project commissioned by the Scottish Government Leeds: Wildland Research Institute.

Harvey, F. (2016). Brexit would damage UK environment, say experts. London: The Guardian.

Highland Council. (2016 \& 2012). Onshore wind energy supplementary guidance. Development and Infrastructure Service, November.

Highland Council. (2015). Creag Riabhach Wind Farm Ltd. North Planning Applications Committee, 4 August.

Jackson, A. L. R. (2014). Bund Naturschutz in Bayern revisited: The required standard of protection under the EU's Habitats Directive prior to a site's adoption as a site of community importance. Journal of Environmental Law, 26, 495-506.

Jackson, T., \& Illsley, B. (2006). Strategic environmental assessment as a tool of environmental governance: Scotland's extension of the European Union SEA Directive. Journal of Environmental Planning and Management, 49(3), 361-383.

Jacobs, F. (2006). The role of the European Court of Justice in the protection of the environment. Journal of Environmental Law, 18(2), 185-205.

Jans, J. H., \& Vedder, H. H. B. (2012). European environmental law: After Lisbon. Groningen: Europa Law Publishing.

John Muir Trust. (2016). Wind farm consented in wild land area. Pitlochry: John Muir Trust.

Joint Nature Conservation Committee (2005). Caithness and Sutherland Peatlands, Information Sheet on Ramsar Wetlands.

Jones, G., \& Scotford, E. (Eds.). (2017). The strategic environmental assessment directive-A plan for success?. Oxford: Hart Publishing.

Joosten, H. (2015). Peatlands, climate change mitigation and biodiversity conservation. Nordic Council of Ministers: Policy brief.

Langston, R.H.W. \& Pullan, J.D. (2003). Windfarms and birds: An analysis of the effect of windfarms on birds, and guidance on environmental assessment criteria and site selection issues. Strasbourg: Council of Europe T-PVS/Inf (2003) 12.

Lee, M. (2017). Accountability for environmental standards after Brexit. Environmental Law Review, 19(2), 89-92.

Lee, M., Armeni, C., de Cendra, J., Chaytor, S., Lock, S., Maslin, M., et al. (2013). Public participation and climate change infrastructure. Journal of Environmental Law, 25(1), 33-62.

MacNab, S. (2016a). Ministers give controversial Highlands windfarm green light. Edinburgh: The Scotsman.

MacNab, S. (2016b). Windfarms are 'waved through' by SNP ministers. Edinburgh: The Scotsman.

MacNab, S. (2017). Scottish Government push turbines by overturning local decisions. Edinburgh: The Scotsman.

Marsden, S. (2008). Strategic environmental assessment in international and European law: A practitioner's guide. London: Earthscan.

Marsden, S. (2011). The Espoo Convention and Kiev Protocol in the European Union: Implementation, compliance, enforcement and reform. Review of European Community and International Environmental Law, 20(3), 267-276.

Marsden, S. (2012). Direct public access to EU Courts: upholding public international law via the Aarhus Convention Compliance Committee. Nordic Journal of International Law, 81(2), 175-204.

Marsden, S., \& Brandon, E. (2015). Transboundary environmental governance in Asia: Practice and prospects with the UNECE Agreements. Cheltenham: Edward Elgar.

McCartney, F. (2011). The aarhus convention: Can Scotland deliver environmental justice? Edinburgh Law Review, 15, 128-133.

McDonald, H. (2016). Belfast court rejects two challenges to Brexit. London: The Guardian.

McKenna, K. (2017). Gannets, puffins, kittiwakes: Birds at risk in Scottish windfarm surge. London: The Guardian.

McKie, A. (2016). Impact assessments still important. The Journal of the Law Society of Scotland. http:// www.journalonline.co.uk/Magazine/61-10/1022372.aspx. 
McMorran, R., Price, M. F., \& Warren, C. R. (2008). The call of different wilds: The importance of definition and perception in protecting and managing Scottish wild landscapes. Journal of Environmental Planning and Management, 51(2), 177-199.

Merrick, R. (2016). Brexit is likely to end up before EU's highest court, says Europe's top judge. London: The Independent.

Metcalfe, C. (2012). Aarhus, wind farms and public accountability (pp. 27-30). Autumn: Wild Land News. Opinion of the Court. First Division, Inner House, Court of Session (2017). CSIH 31. 16 May 2017.

Pagano, M. (2013). Exclusive: UN ruling puts future of UK wind farms in jeopardy-Tribunal warns that the Government acted illegally by denying public participation. London: The Independent.

Pallemaerts, M. (Ed.). (2011). The Aarhus Convention at ten: Interactions and tensions between conventional international law and EU environmental law. Groningen: Europa Law Publishing.

Protocol on Strategic Environmental Assessment to the Convention on Environmental Impact Assessment in a Transboundary Context. (2003). UN Treaty Series 2685, UN Economic Commission for Europe, Kiev, Ukraine.

Peterkin, T. (2017). Nicola Sturgeon 'resets' indyref2 plans. Edinburgh: The Scotsman.

Ramsar Convention. (2012). Guidance for addressing the implications for wetlands of policies, plans \& activities in the energy sector, Resolution XI.10, Bucharest.

Reid, C. T. (2016a). Brexit and the future of UK environmental law. Journal of Energy \& Natural Resources Law, 34(4), 407-415.

Reid, C.T. (2016b). Environmental law outside the EU. The Journal of the Law Society of Scotland.

Reid, C. T. (2017). Brexit and the devolution dynamics. Environmental Law Review, 19(1), 3-5.

Ross, A., Nash, H., \& Reid, C. T. (2009). The implementation of EU environmental law in Scotland. Edinburgh Law Review, 13, 224-251.

RSPB. (undated). Summary of RSPB objection to 'Lewis Wind Power' wind farm proposal and complaint to the European Commission. RSPB Briefing.

Sarlöv-Herlin, I. \& and G. Fairclough (2013). Introductive interventions for presentations on experiences of landscape identification and assessment: National, regional and local levels'. In paper presented to 13th Council of Europe Meeting of the Workshops for the Implementation of the European Landscape Convention. See: https://rm.coe.int/16802fc13b.

Schrage, W., Bull, K., \& Karadjova, A. (2009). Environmental legal instruments in the UNECE region. Yearbook of International Environmental Law, 19(1), 4-31.

Scotford, E., \& Bowman, M. (2017). Brexit and environmental law: Challenges \& opportunities. Kings Law Journal, 27(3), 416-419.

Scottish Government. (2017). Onshore wind policy statement. Edinburgh: Scottish Government.

Scottish Government. (2016a). Europe and the environment. Edinburgh: Media Release.

Scottish Government. (2016b). Scotland's place in Europe. Edinburgh: Scottish Government.

Scottish Government. (2016c). Consent granted for new Highland wind farm (p. 19). Edinburgh: Scottish Government.

Scottish Government. (2014). Scottish planning policy. Edinburgh: Scottish Government.

Scottish Natural Heritage. (2012). Mapping Scotland's wildness and wild land. Inverness: Scottish Natural Heritage.

Scottish Natural Heritage. (2012b). Strategic locational guidance for onshore wind farms-natural heritage considerations, consultation draft, October, 1-30.

Scottish Natural Heritage. (2003). Wildness in Scotland's countryside, Policy Statement No. 02/03.

Sparrow, A. (2016). High court says parliament must vote on triggering article 50 - as it happened. London: The Guardian.

Stephens, T. (2009). International courts and environmental protection. Cambridge: Cambridge University Press.

Sundseth, K. \& Roth, P. (2014). Article 6 of the habitats directive: rulings of the European Court of Justice. http://ec.europa.eu/environment/nature/info/pubs/docs/others/ECJ_rulings\%20Art_\%206\%20-\% 20Final\%20Sept\%202014-2.pdf.

Treves, T., Tanzi, A., Pineschi, L., Pitea, C., Ragni, C., \& Jacur, F. R. (Eds.). (2009). Non-compliance procedures and mechanisms and the effectiveness of international environmental agreements. The Hague: TMC Asser Press.

Trouwborst, A. (2016). Wilderness protection under the bern convention: The perspective of Europe's large carnivores. In K. Bastmeijer (Ed.), Wilderness protection in Europe-The role of international, European and national law (pp. 160-176). Cambridge: Cambridge University Press.

UK Parliament. (2017). European Union (Withdrawal) Bill 2017-2019. See: http://services.parliament.uk/ bills/2017-19/europeanunionwithdrawal.html. 
UNECE. (2015). Informal network of the Chairs of compliance/implementation bodies under the multilateral environmental agreements. Third meeting, Geneva, 29 June. Note prepared by the Chair of the Aarhus Convention Compliance Committee with the assistance of the secretariat.

UNECE. (2016). The role of strategic environmental assessment in renewable energy planning. Sub-session at the seventh International Forum on Energy for Sustainable Development, Baku, 21 October.

Velázquez Gomar, J. O. (2016). Environmental policy integration among multilateral environmental agreements: The case of biodiversity. International Environmental Agreements, 16, 525-541.

Watson, J. E. M., Shanahan, D. F., Di Marco, M., Allan, J., Laurance, W. F., Sanderson, E. W., et al. (2016). Catastrophic declines in wilderness areas undermine global environment targets. Current Biology, 26, $1-6$.

Watts, J. (2017). Brexit: Supreme Court President calls for greater clarity on legal ramifications of EU withdrawal. London: The Independent.

Woolley, O. (2015). Ministerial duties under the wild birds directive and judicial review. The Edinburgh Law Review, 19, 424-428. 